\title{
Market Development Strategy for PT A from the Side of Capabilities and Potential Customers
}

\author{
Desy Alfa Irianti \\ Magister Management \\ Faculty of Economic and Business, Universitas Indonesia \\ Jakarta, Indonesia \\ desyalfai@gmail.com
}

\begin{abstract}
PT A is a small and medium enterprise (SME) engaged in manufacturing of dies, precision parts, checking fixtures, machinery, and molding for automotive production. In augmenting its sales, PT A wants to widen the market to include non-automotive industry because their products can be used in other industries as well. Unfortunately, the owner did not know the potential of the products. The present study helps PT $A$ in understanding the capabilities and potentials of customers in the non-automotive market as well as to create strategies for market development. The data were obtained through a series of structured interviews with employees of PT $A$ and non-automotive companies in Delta Silicon Cikarang to reveal their needs and the ability of PT A to meet the customers' needs. The results of structured interviews were analyzed using several tools to view the capabilities using Core Competence Analysis and to examine the potential use of Customer Potential Analysis. The final result is determined by TOWS Matrix. From the analysis, several strategies for market development emerged: (1) reposition products by promoting cheap products and fast production, (2) expand market channel into the plastics, base metal products, and electronics industries, (3) revise and improve capability in production processes to enter new markets, (4) add a new line of current products, which is an advanced process after manufacturing dies and molds.
\end{abstract}

Keywords-Core Competence Analysis, Customer Potential Analysis, Market Development Strategy, Non-Automotive Market, Small and Medium Enterprise (SME)

\section{INTRODUCTION}

Indonesia's economic growth is supported by the manufacturing industry. According to BPS data described by

\author{
Hanrozan Haznam \\ Magister Management \\ Faculty of Economic and Business, Universitas Indonesia \\ Jakarta, Indonesia \\ hanrozan@yahoo.com
}

Darmawan [1], the manufacturing industry contributed $18.18 \%$ up to IDR 2,089 trillion to the 2015 GDP, which rose from $17.89 \%$ amounting to only IDR 1,884 trillion in 2014. The automotive manufacturing industry has experienced a high growth rate. In 2013, it reached $14.95 \%$, which was the highest compared to other industries. Increase in Indonesian population and motor vehicle users is one of the main reasons cited for growth in the automotive sector. In an effort to increase automotive production, there was a need for automotive manufacturing companies such as PT A.

PT A is a B2B company engaged in manufacturing dies, precision parts, checking fixtures, machining, and molding that are useful in the manufacture of components of automobile parts. Mr. A established PT A on October 22, 2011. PT A's annual turnover is approximately IDR 18.000.000.000 contributed by the sale of its products, namely dies and molds. Unfortunately, the features of dies and molds can be reused for several years. A die and mold manufacturer depends on customers' project because it is used in mass production. Dies and molds will be reordered if the old product model is no longer in use or damaged. In general, one customer only orders dies or molds just once to thrice a year. Therefore, there is a need for market or product development in order to maintain or improve PT A's turnover. Currently, the intended market is only the automotive industry while its products can be used for nonautomotive industry as well.

In addition to the explanation for the condition of its products, the Ministry of Industry [2] report shows the increase and decrease of production in the first quarter of 2017 against the first quarter of 2016 (year on year).

TABLE I. INCREASE AND DECREASE OF PRODUCTION IN 2016-2017

\begin{tabular}{|c|c|}
\hline Industry & Production Movement \\
\hline Chemicals and Chemicals Goods & $\uparrow 9.59 \%$ \\
\hline Food and Beverages & $\uparrow 8.2 \%$ \\
\hline Leather: Leather Goods and Foot Wear & $\uparrow 7.12 \%$ \\
\hline Rubber: Rubber Goods and Plastic & $\uparrow 7.8 \%$ \\
\hline Pharmacy: Chemical and Traditional Drugs & $\uparrow 6.29 \%$ \\
\hline Wood: Goods from Wood, Rattan, and Cork & $\downarrow 0.37 \%$ \\
\hline Textile & $\downarrow 1.04 \%$ \\
\hline Fashion & $\downarrow 1.42 \%$ \\
\hline Automotive & $\downarrow 2.36 \%$ \\
\hline Alcohol Beverages & $\downarrow 4.53 \%$ \\
\hline
\end{tabular}


Table 1 shows that the increase in the number of nonautomotive industries, while the automotive industry shows decreased production. Increase in production implies the need for dies and molds. This could suggest a potential for PT A to enter the non-automotive market.

The present study focuses on Delta Silicon Cikarang because it is located nearer to PT A in Delta Silicon 3. Moreover, PT A has not maximized its market in Delta Silicon, which has a huge potential. The current customers of PT A are still on average outside the Delta Silicon area, such as Delta Mas, Karawang, and MM 2100 Industrial Estate. In addition to the identification of non-automotive companies in Delta Silicon, there are many non-automotive companies that PT A can cater. However, companies need to know how to enter the non-automotive market or any other industry in order to expand its market.

Therefore, in order to assist PT A in expanding its market, the present study aims (1) to know the capabilities of PT A to expand its market, (2) to understand the potential of non-automotive market so that the company can identify the needs and market demand in accordance with its capabilities, and (3) to create a strategy based on its capability and market potential to facilitate PT A's market expansion.

\section{MethodolOGY}

This study uses a business coaching framework to answer the existing problems with appropriate theories (Fig 1).

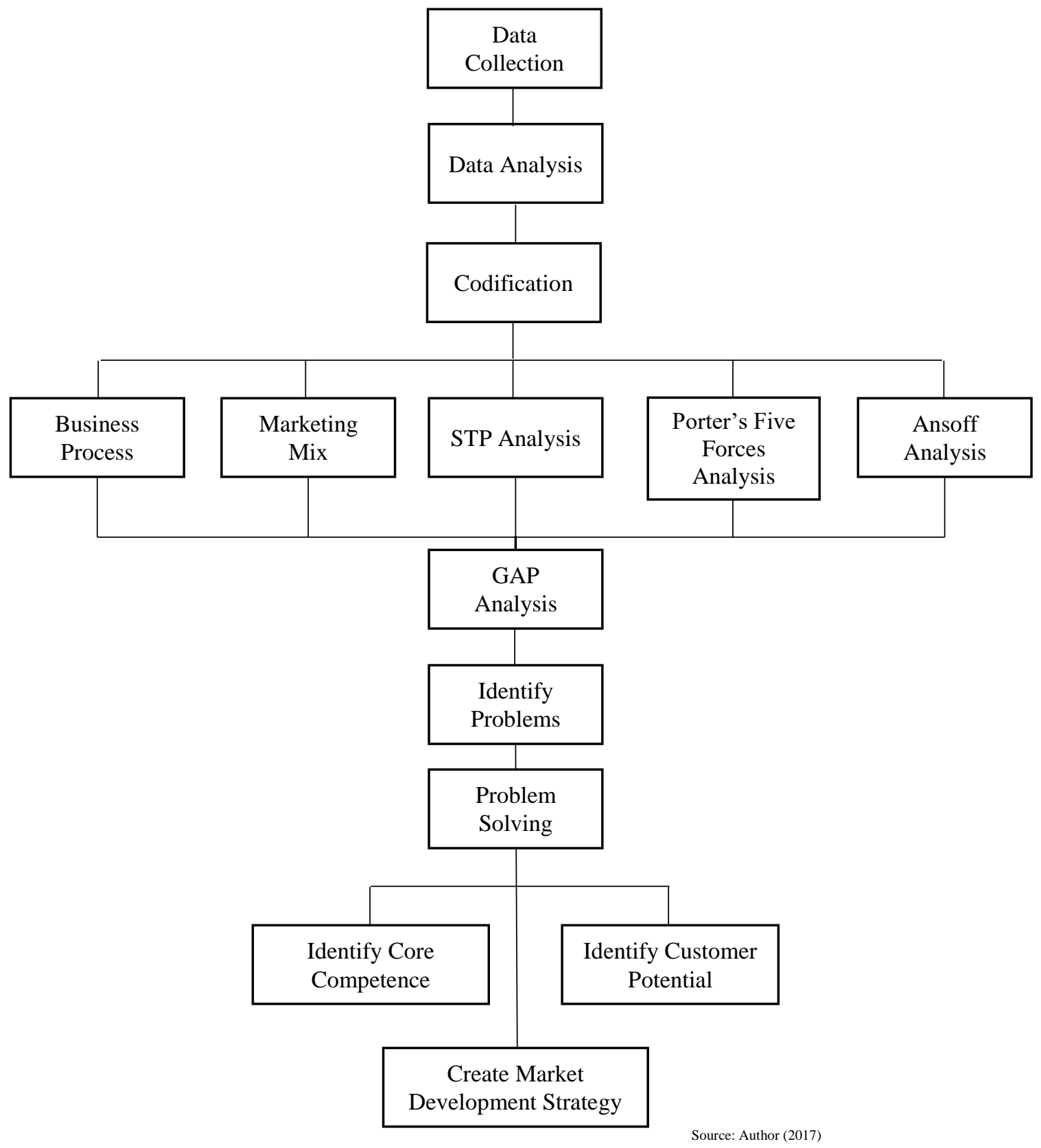

Fig. 1. Business coaching framework 


\section{A. Data Collection}

Data collection techniques used in this business coaching process adopted various methods based on data type, namely primary and secondary. Primary data were obtained through observation and interview. Secondary data were derived from internal and external data.

\section{B. Data Analysis}

This study uses qualitative research, which is a nonstructural study giving insight and understanding of a problem [3]. Data were collected through interviews, observation, and external data for analysis. The data obtained begin sorted, then it will be used continuously during business coaching as the needed.

\section{Codification}

Codification is used to facilitate researchers in distinguishing one data from the other. This process begins with collecting the relevant data for the purpose of fostering this business. Therefore, each type of data is coded into several categories. In present study, it is categorized as follows:

- Business Process: Stages of PT A's business processes are as follows: (1) Identify customer needs based on the consumer's desire for a kind of product. If the desired product can be manufactured by PT A, consumers can directly order the product; (2) Book the product, if the consumer does not have their own design, the consumer only explains about the desired product and the engineer will design it; (3) Design analysis and define raw materials; (4) Price negotiation; (5) Production at PT A is still done manually, thus increasing the frequency of possible errors; (6) Quality control, according to the information obtained from the production head, the rejection level should not exceed $1 \%$ but it is actually $3.14 \%$; (7) Assembly of parts; (8) Trial of the dies and mold are done using a stamping machine or injection. This stage is done outside the company because the machine is not owned by PT A; (9) Shipping; (10) Product acceptance.

- Marketing Mix: According to Kotler in Wardhani (2016), the marketing mix is a tool that helps companies respond to what markets expect. Marketing mix has four components, commonly called 4Ps: product, price, place, and promotion.
- STP Analysis: According to Kotler and Keller (2012), owing to various types of customers with different kinds of needs, a company must divide the entire market, choose the best segment, and design strategies to serve the choice of profit-generating segments. This process consists of three steps: market segmentation, setting the target market, and market positioning.

- Porter's Five Forces Analysis: Given the current industrial conditions, PT A can use the five forces analysis proposed by Michael Porter. According to Porter in Gamble [4], the Five Forces analysis helps to analyze the industry as a whole against the business being undertaken by visualizing the current business conditions in order to help businesses find their competitive advantage. Five forces determine the intensity of competition in an industry: (1) threat of substitute products, (2) threat of new entrants, (3) bargaining power of suppliers, (4) bargaining power of buyer, and (5) rivalry among existing competitors. Ansoff Analysis: used to illustrate an alternative corporate development strategy that focuses on new markets and products or markets and products currently owned by an organization [5]. The four alternatives include market penetration (existing product/existing market), market development (existing product/new market), product development (new product/existing market), and diversification (new product/ new market).

\section{GAP Analysis}

In determining the problem to be solved, it is important to identify the gaps within the company. Table II presents the gap analysis of PT A.

\section{E. Identify Problems}

Once the gap in PT A has been identified, the most critical problem must be found and resolved. The present study focuses on determining the problem by weighting and valuing each gap as follows:

- Weight : 1-100, where

$1=$ is not very urgent and

$100=$ is very urgent

- Weight :1-10, where

$1=$ is very unworkable and

$10=$ is very workable

- $\quad$ Contribution $=$ Score $\mathrm{x}$ Weight

- $\quad \%=($ contribution / total contribution $) \times 100 \%$

TABLE II. GAP ANALYSIS OF PT A

\begin{tabular}{|c|c|c|c|}
\hline Analysis Method & Actual Condition & Ideal Condition & Planning \\
\hline Business Process & $\begin{array}{l}\text { The company does not have a } \\
\text { management system for production control }\end{array}$ & The company has a management system & $\begin{array}{l}\text { Develop a technology-based } \\
\text { management system program }\end{array}$ \\
\hline $\begin{array}{l}\text { STP and Ansoff } \\
\text { Analysis }\end{array}$ & $\begin{array}{l}\text { The company does not know market } \\
\text { potential other than automotive industry }\end{array}$ & $\begin{array}{l}\text { The company knows market potential } \\
\text { other than automotive industry }\end{array}$ & $\begin{array}{l}\text { Mapping the potential that exists for } \\
\text { markets other than automotive } \\
\text { industry }\end{array}$ \\
\hline $\begin{array}{l}\text { Porter's } 5 \text { Forces } \\
\text { Analysis }\end{array}$ & $\begin{array}{l}\text { The company does not know about their } \\
\text { competitors clearly }\end{array}$ & $\begin{array}{l}\text { The company knows about their } \\
\text { competitors clearly }\end{array}$ & Mapping competitors \\
\hline Marketing Mix & The website is less informative & The website has complete information & Enrichment of information in website \\
\hline Business Process & $\begin{array}{l}\text { The company have not maximized the } \\
\text { ability of the company by only accepting } \\
\text { job order }\end{array}$ & $\begin{array}{l}\text { Optimization of company capability by } \\
\text { making mass production product }\end{array}$ & $\begin{array}{l}\text { Creating strategies to maximize the } \\
\text { company's ability to make mass } \\
\text { production products }\end{array}$ \\
\hline Business Process & Limited of production skill & Increased skill to lower reject ratio & $\begin{array}{l}\text { Develop training programs related to } \\
\text { production }\end{array}$ \\
\hline
\end{tabular}


TABLE III. SCORING OF GAP ANALYSIS PT A

\begin{tabular}{|c|c|c|c|c|c|c|c|c|c|}
\hline Problems & $\begin{array}{l}\text { Score } \\
\text { by A }\end{array}$ & $\begin{array}{l}\text { Weight } \\
\text { by A }\end{array}$ & $\mathbf{S} \times \mathbf{W}$ & $\% \mathrm{~A}$ & $\begin{array}{l}\text { Score by } \\
\text { Author }\end{array}$ & $\begin{array}{l}\text { Weight } \\
\text { by } \\
\text { Author }\end{array}$ & $\mathbf{S} \times \mathbf{W}$ & $\begin{array}{l}\% \\
\text { Author }\end{array}$ & $\begin{array}{l}\text { Final } \\
\text { Score }\end{array}$ \\
\hline $\begin{array}{l}\text { Does not have a management } \\
\text { system for production control }\end{array}$ & 80 & 8 & 640 & $15 \%$ & 60 & 8 & 480 & $12 \%$ & $13 \%$ \\
\hline $\begin{array}{l}\text { Does not know market } \\
\text { potential other than automotive } \\
\text { industry }\end{array}$ & 90 & 9 & 810 & $19 \%$ & 95 & 9 & 855 & $21 \%$ & $20 \%$ \\
\hline $\begin{array}{l}\text { Does not know about the } \\
\text { competitors clearly }\end{array}$ & 90 & 9 & 810 & $19 \%$ & 95 & 9 & 855 & $21 \%$ & $20 \%$ \\
\hline The website is less informative & 70 & 8 & 560 & $13 \%$ & 75 & 6 & 450 & $11 \%$ & $12 \%$ \\
\hline $\begin{array}{l}\text { Have not maximized the ability } \\
\text { of the company by only accept } \\
\text { job order }\end{array}$ & 90 & 7 & 630 & $15 \%$ & 90 & 7 & 630 & $15 \%$ & $15 \%$ \\
\hline Limited of production skill & 95 & 9 & 855 & $20 \%$ & 95 & 9 & 855 & $21 \%$ & $20 \%$ \\
\hline
\end{tabular}

In this study, both the assessments are done by the company itself and also by the author for an equal view on the problems faced. Table III present the results.

These results show that three issues have the highest value $(20 \%)$, for instance, unaware of the potential of nonautomotive market, lack of clarity regarding the competitors, and limited production skill. The present study focuses on the problems of PT A with regard to lack of knowledge of the potential market other than automotive industry. The importance of knowing the unexplored market potential is to help PT A to overcome the company's main issue, for example, decline in turnover, so that the immediate problem is quickly resolved.

\section{F. Problem Solving}

To answer the problems to be solved, then find out by using both theories, which is Core Competence Analysis and Customer Potential Analysis are both used to resolve these problems. Core Competence Analysis focuses more on the company's internal conditions to identify the company's ability to expand its market to non-automotive market. Customer Potential Analysis is used to view the external conditions from the customer side.

\section{G. Create Market Development Strategy}

Further strategies can be made for market expansion toward non-automotive industry after understanding both the internal and external conditions through core competence analysis and customer potential analysis. This strategy uses a comparison of both previous analyzes.

\section{CONCEPTUAL BACKGROUND}

\section{A. Core Competence Analysis}

Hamel and Prahalad [6] define competence as a set of capabilities and technologies compared to discrete or technological abilities. Key competencies are a unique source of competitive advantage and contribute to customer value or cost. Each major competency can be a critical success factor, but not all competitive advantages are major competencies.

Prahalad and Hamel [7] elucidate three key factors that can help the company to identify its main competencies:

- Provide potential access to markets
- Provide Make a significant contribution to the benefits felt by customers

- Become unique and difficult to imitate by competitors

Hafeez, YanBing, and Naila [8] describe the main competence analysis process with references to three steps:

\section{Identifying Key Capabilities}

Identifying key capabilities for the success of a business is the first step. To know the capability, it is necessary to first describe the firm's resources as tangible and intangible assets. Capabilities are those that provide benefits to customers.

\section{Determining Competence}

After identifying the key capabilities, then determine the competence. To determine its competence, it is necessary to consider the capabilities that can provide potential access for companies to various markets. Therefore, it is examined whether the capability possessed can be used for interbusiness.

\section{Determining Core Competence}

After determining the competence, then identify the core competence that is unique, which in turn helps in establishing the core competence that can help achieve a sustainable competitive advantage for a business. The VRIO Analysis tool is used to identify the uniqueness of the company's capabilities. These results show that the most superior key capabilities will become the core competence of a company.

\section{B. Customer Potential Analysis}

Customer potential is the likely future customers of the company. In general, customer potential has the need, urgency, and ability [9]. Campbell and Cunningham [10] state that, before customer potential analysis, a company must determine first who is the customer. The following dimensions help in customer analysis: (1) determining customer needs and desires, (2) attracting customer targets, (3) customer demographics, and (4) current market conditions [11].

Heffernan [12] proposes four methods to understand a potential customer: 


\section{1) Utilizing Using Information from Internet}

Internet is a good source of information. Google Alerts, Mention, and Talkwalker Alerts are tools used to leverage online information to understand more about the existing customers, potential customers, and customer patterns.

\section{2) Interviewing Current Customers}

Current customers are the latest source of information because they have experienced a company's products and are also easily accessible. In addition, if the customer has made repeated purchases, they could give suggestions and accurate comments about the company.

\section{3) Using Competitors}

The potential of customers isn't only seeing by the customer side, but also by learning of the competitor's activities to their customer. Reassessing what competitors do can help a company better understand its future prospects and why customers choose the competitors' products.

\section{4) Utilizing a Professional Social Network}

A company can seek information on the existing market potential by using a professional social network. In addition, these social networks can help companies to expand their connections so that in future they a potential customer.

\section{Market Development Strategy}

Market development is a process of entering new markets to increase revenue and reduce concentration risk by utilizing existing products. This process involves identifying the target market and finding a way to sell it to them [13].

Strategies on entering new market can be seen from internal and external drives. These drives will determine the objectives of the strategy to be applied. Table 4 present the types of strategies in market development [14]:

TABLE IV. TYPES OF STRATEGIES IN MARKET DEVELOPMENT

\begin{tabular}{|l|l|l|}
\hline No & Goal & Strategies \\
\hline 1 & Maintain a position as a product innovator & Increase or revise current product \\
\hline 2 & Maintain current market share position & $\begin{array}{l}\text { Add the current product line; improve or revise current } \\
\text { products; reduce costs }\end{array}$ \\
\hline 3 & Set a foothold in new markets and expand market segments & Add the current product line; reposition the products \\
\hline 4 & Exploit technology in new ways & $\begin{array}{l}\text { Create a new product line; revise or add to the current product } \\
\text { line }\end{array}$ \\
\hline 5 & Utilize the power of distribution & $\begin{array}{l}\text { Create a new product line; revise or add to the current product } \\
\text { line }\end{array}$ \\
\hline 6 & Provide cash generator & $\begin{array}{l}\text { Revise or add to current product lines; reposition the products; } \\
\text { reduce costs }\end{array}$ \\
\hline 7 & Excess capacity or out of season & Create a new product line \\
\hline
\end{tabular}

In determining the strategy to be applied, we need to identify the internal and external conditions to be able to frame a strategy. Therefore, the objectives of the two previous analyses, namely Core Competence Analysis was to see the internal conditions and Customer Potential Analysis was to see external conditions. The results of both the analysis related to the SWOT and TOWS Matrix Analyses.

\section{METHOD AND DATA}

Data for the present study were collected using primary and secondary data collection methods. Primary data collection was through interviews and observation technique. Secondary data were obtained from internal and external data. Internal data were taken from company data regarding company assets, current consumer data, and employee skill data. External data were obtained through the internet on the target customer's profile, as in Delta Silicon. The following techniques of data retrieval were used:

\section{A. Observation}

Observation involves recording patterns of behavior of people, objects, and activities to extract the required information [15]. In the present study, observations were made at the beginning of the visit by observing the company location, building and machinery available, product types, production flow, and company profile of PT A. The observation that has done didn't plan, it's just follow the flow of PT A's work. This observation system is in accordance with the theory of Malhotra [3], and includes personal observation and unstructured observation. Personal observation by a researcher includes direct observation of the actual behavior as it occurs and unstructured observation is an observation made by a researcher by monitoring all phenomena that occur without any specification. Interview

The interview was an in-depth unstructured and direct personal interview, in which a respondent was asked to reveal some basic information on a topic [13]. Interviews were conducted with the marketing and production personnel who are very familiar about the consumers of PT A and the company's ability.

\section{RESUlTS}

\section{A. Core Competence Analysis}

Both tangible and intangible assets of PT A were identified by the analysis. These assets include computerized production machinery, manual production machines, the ability to obtain cheap raw materials, the ability to produce, the ability to produce quickly, cheap product, culture, and work environment. These assets are companies' capability that provide benefits to customers and can be used among businesses. Further, the main competencies were determined by looking at the uniqueness. Each capability can be judged against the four unique attributes: valuable, rare, inimitable, and organized. Each attribute was tested using VRIO analysis using these four attributes. Table V shows the VRIO analysis to determine the uniqueness of creating a sustainable competitive advantage: 
TABLE V. VRIO ANALYSIS OF PT A

\begin{tabular}{|c|c|c|c|c|c|}
\hline Resources & Valuable & Rare & Inimitable & Organized & Competitive Implication \\
\hline \multicolumn{6}{|l|}{ Tangible Assets } \\
\hline Computerized production machines & Yes & No & No & No & Competitive Parity \\
\hline Manual production machines & Yes & No & No & No & Competitive Parity \\
\hline \multicolumn{6}{|l|}{ Intangible Assets } \\
\hline Ability to obtain cheap raw materials & Yes & Yes & Yes & Yes & $\begin{array}{l}\text { Sustained Competitive } \\
\text { Advantage }\end{array}$ \\
\hline Ability in the production process & Yes & No & No & No & Competitive Parity \\
\hline Ability to produce quickly & Yes & Yes & Yes & Yes & $\begin{array}{l}\text { Sustained Competitive } \\
\text { Advantage }\end{array}$ \\
\hline Cheap product & Yes & Yes & Yes & Yes & $\begin{array}{l}\text { Sustained Competitive } \\
\text { Advantage }\end{array}$ \\
\hline Culture and Work Environment & Yes & No & No & No & Competitive Parity \\
\hline
\end{tabular}

PT A's capabilities that offer unique and sustainable competitive advantages include the ability to obtain cheap raw materials, cheap product prices, and the ability to produce quickly. PT A must foster these three capabilities in order to continue to survive with competitors. It is important for those who do not have an advantage or only a competitive parity, because it can be a critical capability that can affect the quality of the desired customer.

\section{a. Customer Potential Analysis}

Heffernan [10] explains four ways to better understand a potential customer:

1. Utilizing Information from Internet

There are several tools to obtain information from the internet, such as Google Alerts, Mention, and Talkwalker Alerts. PT A can use Google Alerts only because this tool has information on the condition in Indonesia derived from various news portals. However, Google Alerts is not entirely complete because when searching for information about the dies and mold industry, not many articles can help. Next, information on non-automotive company in Delta Silicon was taken from an online article and Portal of Bekasi Regency. As many as 102 companies were found.

Of the 102 companies found, $31 \%$ belong to plastic industry, $29 \%$ to basic metal industry companies, and $23 \%$ electronics industry. In addition, two of the three companies in the industry are located in the Delta Silicon 1 area, which is displayed on the mapping of potential consumers. Therefore, in expanding its market to non-automotive sector, PT A can focus on plastic industry companies, base metal products industries, and electronics industries located in Delta Silicon 1.

\section{Interviewing Current Customers}

The existing customers of PT A are PT Fujita Indonesia, PT Toyota Boshoku Indonesia (TBINA), PT Nusa Toyotetsu Corp., PT Nusahadi Citra Harmonis, PT Nichias Metalworks Indonesia, PT FCC Indonesia, PT APM Armada Autoparts (AAA), and PT Grand Surya Techno. PT Nichias Metalwork's Indonesia produces non-automotive products. PT Nichias Sunijaya produces rock wool products.

\section{Using Competitors}

Competitors who have a similar business with PT A's competitors do not only focus on automotive industry, but majority of PT A's competitors are also engaged in automotive and electronics. In addition, competitors already have machines for advanced stages in the process of dies and molds, such as stamping, pressing, injection, and others [14].

\section{Utilizing a Professional Social Network}

A professional social network such as LinkedIn can be used because it can take a direct approach to the related customer. From LinkedIn results, it is found that almost all employees of 102 non-automotive companies in Delta Silicon have a presence on LinkedIn. LinkedIn can be used to find parties concerned for awareness about PT A and the potential products sales to prospective customers. However, the response has been poor.

PT A is associated with Indonesian Mold and Dies Industry Association (IMDIA). IMDIA can be used in establishing relationships with other companies and to promote themselves on the IMDIA website. IMDIA consists of 349 members across Indonesia. Each member can post ads to make it easier for members to attract customers within the IMDIA website.

\section{b. Market Development Strategy}

After analyzing the internal and the external conditions of the company, the strategy to be applied on PT A in its market expansion needs to be determined. The strategy can be developed by considering the strengths and weaknesses obtained from Core Competence Analysis, compared with the opportunities and threats obtained from Customer Potential Analysis. The objective of this mapping is to determine the strategy for the sustainability of PT A and the wish to expand its market to non-automotive market. In this mapping, strengths, weaknesses, opportunities, and threats are determined with SWOT Analysis (Table VI).

After determining the strengths, weaknesses, opportunities, and threats with SWOT Analysis, further mapping with TOWS Matrix is made (Tables VII and VIII).

Once the strategy for market expansion of PT A is known, then further recommendation action to execute strategy can be made. These actions are based on the results of field analysis that can be done by PT A (Table IX) 
TABLE VI. SWOT ANALYSIS OF PT A

\begin{tabular}{|c|c|c|c|c|}
\hline \multirow{2}{*}{ No. } & \multicolumn{2}{|l|}{ Core Competence Analysis } & \multicolumn{2}{|l|}{ Customer Potential Analysis } \\
\hline & Strengths & Weaknesses & Opportunities & Threats \\
\hline 1 & $\begin{array}{l}\text { All capabilities in the } \\
\text { production process can be for } \\
\text { inter-business }\end{array}$ & $\begin{array}{l}\text { There is a critical capability } \\
\text { that must be considered, there } \\
\text { is the ability in the production } \\
\text { process }\end{array}$ & $\begin{array}{l}\text { Dies and molds is widely used } \\
\text { for non-automotive industry }\end{array}$ & $\begin{array}{l}\text { Competitors have already } \\
\text { entered the non-automotive } \\
\text { market, the majority toward } \\
\text { the electronics industry }\end{array}$ \\
\hline 2 & $\begin{array}{l}\text { The ability to acquire cheap } \\
\text { raw materials, cheap product } \\
\text { prices, and the ability to } \\
\text { produce quickly is a } \\
\text { sustainable competitive } \\
\text { advantage of PT A }\end{array}$ & $\begin{array}{l}\text { Dies and molds can be used } \\
\text { for long term }\end{array}$ & $\begin{array}{l}\text { The majority of non- } \\
\text { automotive companies are the } \\
\text { plastics industry, base metal } \\
\text { products industry, and } \\
\text { electronics industries in Delta } \\
\text { Silicon 1 }\end{array}$ & $\begin{array}{l}\text { Majority of competitors have } \\
\text { advanced machine dies and } \\
\text { mold process }\end{array}$ \\
\hline 3 & & & $\begin{array}{l}\text { There is networking from } \\
\text { current customers }\end{array}$ & \\
\hline 4 & & & $\begin{array}{l}\text { The number of companies } \\
\text { requiring dies and molds is } \\
\text { incorporated into the } \\
\text { Indonesia Mold and Dies } \\
\text { Industry Association (IMDIA) }\end{array}$ & \\
\hline
\end{tabular}

TABLE VII. MAPPING STRENGTHS AND WEAKNESSES WITH OPPORTUNITIES

\begin{tabular}{|c|c|c|}
\hline & Strengths & Weaknesses \\
\hline Internal & $\begin{array}{l}\text { - All capabilities in the production process } \\
\text { can be for inter-business } \\
\text { - The ability to acquire cheap materials, } \\
\text { cheap product prices, and the ability to } \\
\text { produce quickly is a sustainable } \\
\text { competitive advantage of PT A }\end{array}$ & $\begin{array}{l}\text { - There is a critical capability that must } \\
\text { be considered, there is the ability in } \\
\text { the production process } \\
\text { - Dies and molds can be used for long } \\
\text { term }\end{array}$ \\
\hline Opportunities & & \multirow[b]{2}{*}{$\begin{array}{l}\text { - Revise and improve capability in } \\
\text { production processes to enter the } \\
\text { plastics, base metal products, and } \\
\text { electronics industries. } \\
\text { - Adds a new line of current products, } \\
\text { which is an advanced process after } \\
\text { manufacturing dies and molds for } \\
\text { non-automotive companies. }\end{array}$} \\
\hline $\begin{array}{l}\text { - Dies and molds is widely } \\
\text { used for non-automotive } \\
\text { industry } \\
\text { - The majority of non- } \\
\text { automotive companies are the } \\
\text { plastics industry, basic metal } \\
\text { industry, and electronics } \\
\text { industries in Delta Silicon } 1 \\
\text { - There is networking from } \\
\text { current customers } \\
\text { - The number of companies } \\
\text { requiring dies and molds is } \\
\text { incorporated into IMDIA }\end{array}$ & $\begin{array}{l}\text { - Do repositioning products, not just for } \\
\text { automotive but for non-automotive } \\
\text { industries as well by promoting cheap } \\
\text { products and fast production. } \\
\text { - Expanding market channel into the } \\
\text { plastics, base metal products, and } \\
\text { electronics industries. }\end{array}$ & \\
\hline
\end{tabular}

TABLE VIII. MAPPING STRENGTHS AND WEAKNESSES WITH THREATS

\begin{tabular}{|c|c|c|}
\hline & Strengths & Weaknesses \\
\hline Internal & \multirow{2}{*}{$\begin{array}{l}\text { - All capabilities in the production process } \\
\text { can be for inter-business } \\
\text { - The ability to acquire cheap materials, } \\
\text { cheap product prices, and the ability to } \\
\text { produce quickly is a sustainable } \\
\text { competitive advantage of PT A }\end{array}$} & \multirow{2}{*}{$\begin{array}{l}\text { - There is a critical capability that must } \\
\text { be considered, there is the ability in } \\
\text { the production process } \\
\text { - Dies and molds can be used for long } \\
\text { term }\end{array}$} \\
\hline External & & \\
\hline Threats & \multirow{3}{*}{$\begin{array}{l}\text { - Adding a new line of current products, } \\
\text { which is an advanced process after } \\
\text { manufacturing dies and molds for } \\
\text { companies in the plastics, base metal } \\
\text { products, and electronics industries } \\
\text { - Do repositioning products, not just for } \\
\text { automotive but for non-automotive } \\
\text { industries as well by promoting cheap } \\
\text { products and fast production }\end{array}$} & \multirow{3}{*}{$\begin{array}{l}\text { - Revise and improve capability in } \\
\text { production processes to enter the } \\
\text { plastics, base metal products, and } \\
\text { electronics industries. } \\
\text { - Adding a new line of curren } \\
\text { products, which is an advanced } \\
\text { process after manufacturing dies and } \\
\text { molds for companies in the plastics } \\
\text { base metal products, and electronics } \\
\text { industries }\end{array}$} \\
\hline $\begin{array}{l}\text { - Competitors have already } \\
\text { entered the non- }\end{array}$ & & \\
\hline $\begin{array}{l}\text { automotive market, the } \\
\text { majority toward the } \\
\text { electronics industry } \\
\text { - Majority of competitors } \\
\text { have advanced machine } \\
\text { dies and mold process }\end{array}$ & & \\
\hline
\end{tabular}


TABLE IX. Actions to Market DeVelopment StRategy

\begin{tabular}{|c|c|c|}
\hline No. & Market Development Strategy & Actions \\
\hline 1 & $\begin{array}{l}\text { Do repositioning products, not just for automotive but for non- } \\
\text { automotive industries as well by promoting cheap products } \\
\text { and fast production. }\end{array}$ & $\begin{array}{l}\text { Build awareness and attract customers through company profile, } \\
\text { direct selling, website, and recommendations by highlighting } \\
\text { cheap products and fast production }\end{array}$ \\
\hline \multirow{3}{*}{2} & \multirow{3}{*}{$\begin{array}{l}\text { Expanding market channel into the plastics, base metal } \\
\text { products, and electronics industries. }\end{array}$} & $\begin{array}{l}\text { Build awareness about PT A to network from current customers, } \\
\text { such as PT Nichias Sunijaya in producing rock wool products } \\
\text { for electronics, by entering company profile catalog to the } \\
\text { company }\end{array}$ \\
\hline & & $\begin{array}{l}\text { Join with IMDIA to add information and relationships, as well } \\
\text { as marketing tools }\end{array}$ \\
\hline & & $\begin{array}{l}\text { Give information about PT A to plastic industry companies, base } \\
\text { metal products, and electronics that are already on the company } \\
\text { list }\end{array}$ \\
\hline \multirow[b]{2}{*}{3} & \multirow[b]{2}{*}{$\begin{array}{l}\text { Revising and improving capability in production processes to } \\
\text { enter the plastics, base metals and electronics industries. }\end{array}$} & Regular training for employee \\
\hline & & $\begin{array}{l}\text { Improved skills by making Manufacturing Information System } \\
\text { (MIS) so that production can be controlled by technology. It } \\
\text { helps PT A to add value in the eyes of customers }\end{array}$ \\
\hline \multirow[b]{2}{*}{4} & \multirow{2}{*}{$\begin{array}{l}\text { Adding a new line of current products, which is an advanced } \\
\text { process after manufacturing dies and molds for companies in } \\
\text { the plastics, base metals and electronics industries. }\end{array}$} & Adding services like stamping, pressing, injection, and others \\
\hline & & $\begin{array}{l}\text { Planning the purchase of machines (because they do not have) to } \\
\text { meet the needs of stamping, pressing, injection, and others for } \\
\text { non-automotive companies }\end{array}$ \\
\hline
\end{tabular}

\section{CONCLUSION}

From the study results on the business coaching process at PT A, the following conclusions are made:

- The capability of PT A, which is the ability to have a competitive advantage to expand its market to non-automotive market, are the ability to obtain cheap raw material, cheap product price, and ability to produce quickly. However, there is a critical capability that needs to be considered in PT A, namely the ability of employees in the production process.

- The market potential of non-automotive sector in Delta Silicon Cikarang is $31 \%$ in plastic industry, $29 \%$ in basic metal products industry, and $23 \%$ in the electronics industry. In addition, the majority of the three industrial companies are located in the Delta Silicon 1 area.

- PT A's market development strategies to enter nonautomotive market are as follows:

1. Reposition products not only for automotive industries but also for non-automotive sector as well as promote cheap products and fast production.

2. Expand market channel into the plastics, base metal products, and electronics industries.

3. Revise and improve capability in production processes to enter the plastics, base metal products, and electronics industries.

4. Add a new line of current products, which is an advanced process after manufacturing dies and molds for companies in the plastics, base metal products, and electronics industries.

\section{REFERENCES}

[1] Darmawan, A. (2016). Perkembangan Industri Manufaktur di Indonesia Tahun 2015-2016, 2

[2] Kementrian Perindustrian. (2017). Analisis Perkembangan Industri. Jakarta.

[3] Malhotra, N. K. (2010). Marketing Research (6 $6^{\text {th }}$ ed.). New Jersey, NJ: Pearson Education, Inc.

[4] Gamble, J. E., Peteraf, M., Thompson, A. A. (2015). Essentials of Strategic Management $\left(4^{\text {th }}\right.$ ed.). New York: McGraw-Hill Education.

[5] Wardhani, R. A. (2016). Mengembangkan Kompetensi Sumber Daya Manusia melalui Penerapan Individual Development Plan (Business Coaching pada PT. A Presisi Indonesia). University of Indonesia.

[6] Hamel, G., \& Prahalad, C. K. (1994). Competiting for The Future. Boston, MA: Harvard Business School Press.

[7] Prahalad, C. K. \& Hamel, G. (1990). The Core Competence of the Corporation. Harvard Business Review, Vol. 68, Issue 3, p. 79-91 1990.

[8] Hafeez, K., Zhang, Y., \& Malak, N. (2002). Core competence for sustainable competitive advantage: A structured methodology for identifying core competence. IEEE transactions on engineering management,49(1), 28-35.

[9] (Thompson, 2004)

[10] Campbell and Cunningham (1983)

[11] Jesamine. (2014). Customer Analysis: How To Effectively Target The Market. Diakses pada 12 Oktober 2017 dari https://blog.udemy.com/customer-analysis/

[12] Heffernan, P. (2015). 5 Ways to Research Your Potential Customers. Diakses pada 12 Oktober 2017 dari https://www.marketing-partners.com/conversations2/5-waysto-research-your-potential-customers.

[13] Spacey, J. (2017). 6 Types of Market Development. Diakses pada 22 November 2011 dari https://simplicable.com/new/ market-development.

[14] Walker and John, 2014

[15] Harina, Raiva. (2017). Strategi Pengembangan Pasar Baru untuk PT A dari Sisi Pemetaan Kompetitor. Jakarta: Universitas Indonesia. 